\title{
The acquisition of phototrophy: adaptive strategies of hosting endosymbionts and organelles
} Matthew D. Johnson

Department of Biology, Woods Hole Oceanographic Institution, Woods Hole, MA 02543, USA

mattjohnson@whoi.edu

\begin{abstract}
Many non-photosynthetic species of protists and metazoans are capable of hosting viable algal endosymbionts or their organelles through adaptations of phagocytic pathways. A form of mixotrophy, acquired phototrophy $(\mathrm{AcPh})$ encompasses a sweet of endosymbiotic and organelle retention interactions, that range from facultative to obligate. AcPh is a common phenomenon in aquatic ecosystems, with endosymbiotic associations generally more prevalent in nutrient poor environments, and organelle retention typically associated with more productive ones. All AcPhs benefit from enhanced growth due to access to photosynthetic products, however the degree of metabolic integration and dependency in the host varies widely. AcPhs are mixotrophic, using both heterotrophic and phototrophic carbon sources. AcPh is found in at least four of the major eukaryotic supergroups, and is the driving force in the evolution of secondary and tertiary plastid acquisitions. Mutualistic resource partitioning characterizes most algal endosymbiotic interactions, while organelle retention is a form of predation, characterized by nutrient flow (i.e. growth) in one direction. $\mathrm{AcPh}$ involves adaptations to recognize specific prey or endosymbionts and to house organelles or endosymbionts within the endomembrane system but free from digestion. In many cases, hosts depend upon $\mathrm{AcPh}$ for the production of essential nutrients, many of which remain obscure. The practice of $\mathrm{AcPh}$ has led to multiple independent secondary and tertiary plastid acquisition events among several eukaryote lineages, giving rise to the diverse array of algae found in modern aquatic ecosystems. This review highlights those AcPhs that are model research organisms for both metazoans and protists. Much of the basic biology of AcPhs remains enigmatic, particularly 1) which essential nutrients or factors make certain forms of $\mathrm{AcPh}$ obligatory, 2) how hosts regulate and manipulate endosymbionts or sequestered organelles, and 3) what genomic imprint, if any, $\mathrm{AcPh}$ leaves on non-photosynthetic host species.
\end{abstract}


Key words: Acquired phototrophy, mixotrophy, kleptoplastidy, karyoklepty, endosymbiosis

\section{Introduction}

Numerous species of protists and metazoans have adapted functional nutritional modes in which they gain the capacity for phototrophy mediated carbon acquisition through symbiotic associations with algae or by a specialized form of predation called organelle retention. The later process is fundamentally distinct from endosymbiosis in that it involves the predacious capture of an alga and subsequent removal and temporary maintenance of one or more organelles, including a plastid (= chloroplast). The term kleptoplastidy is sometimes used to describe the sequestration of an alga plastid (e.g. Lewitus et al 1999), however, in many cases the number of organelles retained, as well as their functionality, has not been sufficiently tested to warrant a conceptual distinction. The temporary acquisition of phototrophy through endosymbiosis or organelle retention occurs in diverse lineages of eukaryotes (Fig. 1), including the alveolata, katablepharidophyta, rhizeria, and metazoa (Stoecker et al. 2009). While endosymbiosis is far more recognized as an important ecological and evolutionary process, the temporary enslavement of algal organelles yields similar metabolic and trophic niches. Both algal endosymbiosis and organelle retention fall almost exclusively within the trophic classification of mixotrophy, combining heterotrophic and phototrophic organic carbon acquisition (Jones 1994). AcPh is widespread amongst protists in aquatic ecosystems, and generally results in the repackaging of photosynthetic production into larger size fractions. This can have important ecological consequences, including the enhancement of trophic transfer efficiency through increased gross growth efficiency of the host. In this review I will focus on physiological and adaptive attributes of well-characterized AcPhs, and will discuss the ecological and evolutionary benefits of these phenomena. The low number of well-studied AcPhs underscores the need for further basic research in these areas. This review will only include interactions between eukaryotes (i.e. between eukaryotic algae and their hosts or predators) and will cover a diverse array of protistan and metazoan hosts. Other recent reviews on $\mathrm{AcPh}$ include an emphasis on the ecological (Stoecker et al. 2009) and evolutionary (Raven et al. 2009) implications of the phenomenon, a theoretical analysis of mixotrophy (Flynn and Mitra 2009), and reviews specifically on organelle retention (Rumpho et al. 2006) and endosymbiosis (Venn et al. 2008). 


\section{The physiology of endosymbiosis}

In this review, endosymbiosis will refer to interactions between two potentially autonomous eukaryotic organisms and will not consider those species that have stable and reduced endosymbionts (e.g. Kryptoperidinium foliaceum; (Horiguchi and Pienaar 1991). Endosymbiotic associations involving algae are a widespread phenomenon in aquatic ecosystems, but are mostly restricted to lichens in terrestrial habitats. The majority of eukaryotic algal endosymbionts are either members of the freshwater green algal class Chlorophyceae (e.g. Chlorella) or marine dinoflagellates. While members of other algal phyla form endosymbiotic associations, none are as widespread or specialized as endosymbionts within the green and dinoflagellate algae. In many cases, endosymbiotic hosts are obligate mixotrophs and cannot survive without their symbionts; this is particularly true for cnidarian (e.g. corals) hosts of Symbiodinium. In contrast, perhaps no eukaryotic algal endosymbiont that is still in possession of its cell wall has been shown to be truly an obligate symbiont (but see (Kato and Imamura 2008b, 2009).

Endosymbiosis generally leads to enhanced ecosystem production and greater accumulation of algal biomass due to hosts providing a refuge from predation and the efficient recycling of metabolites (Trench 1979; Reisser 1986). Perhaps the most striking example of this are the cnidarian-Symbiodinium associations that form tropical coral reefs. In general, endosymbiosis can be viewed as a mutualistic phenomenon, selected for in low nutrient environments where resource limitation leads to low food abundance for heterotrophs and inorganic nutrient limitation in phototrophs. Indeed, among protists and metazoa in aquatic habitats, endosymbiosis is far more common in tropical and/or, low nutrient environments (Stoecker et al. 2009). Among the endosymbiotic associations not featured below are numerous associations between various marine metazoa and Symbiodinium or other dinoflagellates, such as platyhelminth flatworms, tridacnid giant clams, nudibranchs, hadromerid sponges, and certain coronate (Linuche unguiculata) and rhizostomeae (Cassiopea spp.) medusa (Trench 1979; Vicente 1990; Wägele and Johnsen 2001), or between freshwater green algae and sponges (Williamson 1979). Numerous protistian endosymbiotic associations have also been neglected here, including most freshwater (Berninger et al. 1986) and marine (Lobban et al. 2002; Lobban et al. 2005) ciliates, planktonic radiolarians (Gast and Caron 2001) and the dinoflagellate Noctiluca scintillans (Hansen et al. 2004). 


\section{Paramecium and Chlorella}

In freshwater ecosystems, many species of ciliates can host endosymbiotic Chlorella spp. (Reisser 1986; Finlay et al. 1988), with associations that range from transient to persistent facultative endosymbiosis (Stoecker et al. 2009). Undoubtedly the best-characterized protistan endosymbiont host is the freshwater ciliate Paramecium bursaria. P. busaria is a mixotrophic ciliate, gaining sustenance from photosynthate released by its endosymbionts, while the majority of its carbon needed for growth is derived from heterotrophic digestion of engulfed bacterial and protist prey (Reisser 1992) (Table 1, Fig. 2a). Endosymbiotic Chlorella are individually housed within a non-digestive host membrane, the perialgal vacuole, and can number 300-500 per Paramecium in natural populations (Reisser 1991). In nature, Paramecium busaria are nearly always host to Chlorella endosymbionts, which are inherited by their daughter cells (Reisser 1992; Tonooka and Watanabe 2002). However, in culture the ciliate can be induced to bleach and survive only on heterotrophy. Carbon dioxide from Paramecium respiration acts as the major substrate for endosymbiont photosynthesis, while the Chlorella cells release about $57 \%$ of their photosynthate back to their host, the majority of which is in the form of maltose (Reisser 1976; Reisser and Benseler 1981) (Fig. 2a). Most strains of Chlorella isolated from the environment or non-ciliate hosts (e.g. Chlorohydra) have little success in becoming endosymbionts of Paramecium, while strains isolated from Paramecium or other ciliates usually establish a symbiosis (Kodama and Fujishima 2007; Summerer et al. 2007). One strain of Chlorella (F36-ZK) isolated from a Japanese strain of Paramecium has revealed constitutive amino acid transport systems, absent in free-living isolates (Kato and Imamura 2008b). This Chlorella strain lacks nitrate reductase activity (Kamako et al. 2005), and instead may rely upon its host to proved amino acids, presumably acquired by bactivory (Fig. 2a). However, the extent of ammonia uptake by strain F36-ZK has not been sufficiently investigated. Strain F36-ZK also appears to possess a glucose sensing receptor which increases uptake of serine in the presence of glucose and can be inhibited by $\mathrm{Ca}^{2+}$ (Kato and Imamura 2008a). Such regulatory factors may explain why symbiotic Chlorella are difficult to culture after isolation from their hosts (Kato and Imamura 2009). Endosymbiotic P. busaria cells can take up ammonia and glutamine while bleached cells excrete it as waste (Reisser 1986). In nature, however, much of their nitrogen requirements are likely satisfied through recycling of digested prey cells (Albers and 
Wiessner 1985). Bacterial ingestion increases in cells with endosymbionts, which results in greater endosymbiont density (Berk et al. 1991), a likely result of increased access to nitrogen.

\section{Foraminifera-algal endosymbiosis}

Endosymbiotic associations within the Rhizaria are widespread among the Foraminifera and radiolarian classes Acantharea and Polycystinea (Anderson 1983; Hemleben et al. 1989; Caron and Swanberg 1990; Caron et al. 1995; Gast and Caron 2001). Nearly all species of benthic foraminifera are believed to possess algal endosymbionts or retain plastids from algal prey (Stoecker et al. 2009). Symbionts of planktonic and benthic foraminifera are known to include various species of diatoms, red algae, dinoflagellates, haptophytes, and chlorophytes (Lee 2006; Stoecker et al. 2009). Large specimens of the foraminifera Orbulina universa may possess 7000 Gymnodinium beii endosymbionts per cell (Spero and Parker 1985) (Fig. 1), while planktonic radiolarians may have 20,000 per cell (Spero and Angel 1991). A well-established link has been shown between calcification rates and endosymbiont photosynthetic production in some foraminifera (Lee and Zucker 1969; Duguay 1983; Fujita and Fujimura 2008). In perforate species, respired carbon appears to enter photosynthetic pathways and is then partially recycled in the carbonate skeleton, while no such link is found in imperforate species, indicating a much smaller internal pool of inorganic carbon (Kuile ter and Erez 1987; ter Kuile and Erez 1987; Terkuile and Erez 1991).

Many benthic tropical sediments are rich in endosymbiotic foraminifera and can act as important sources of primary production. Estimates of gross contributions to benthic primary production of the Symbiodinium-containing foraminifera Marginopora kudakajimensis in a Pacific crest and back reef community are between 1-11\% annually (Fujita and Fujimura 2008). In endosymbiotic foraminifera the role of $\mathrm{AcPh}$ in cellular carbon requirements for growth varies with species (Lee and Bock 1976; ter Kuile et al. 1987; Faber and Lee 1991; Lee 2006). In the foraminifera Archaias angulatus and Sorites marginalis nearly 10 times more carbon is gained through feeding compared to released photosynthate when food is available (Lee and Bock 1976). However, in other large benthic foraminifera species, half of the carbon required for growth may be met by photosynthetic release under low food regimes (ter Kuile et al. 1987). Many species of benthic foraminifera are not strictly obligate mixotrophs, but require photosynthesis to 
reach maximum growth rates. The benthic foraminifera Peneroplis planatus selectively feeds on certain diatom species, failing to grow when starved, growing slowly in dark, and reaching maximum growth in light (Faber and Lee 1991). Among benthic foraminifera species that host diatoms, the major endosymbiont photosynthetic products are thought to be lipids and glycerol (Lee 2006).

The potential contribution of photosynthesis to host carbon requirements in pelagic foraminifera also varies widely between and among hosts, but may play a greater role in overall carbon metabolism than in benthic species. Measurements of pelagic sarcodines from the Sargasso Sea suggest that symbiont fixation rates vary between $0.0076-0.070 \mathrm{mg} \mathrm{C}\left(\mathrm{mg} \mathrm{C}^{-1} \mathrm{~h}^{-1}\right.$, amounting to $80 \%$ of carbon requirements of host-symbiont consortia (Caron et al. 1995) (Table 1). In the pelagic foraminiferan Gloigerinoides sacculifer, gross photosynthetic oxygen evolution $\left(18.1 \mathrm{nmol} \mathrm{O}_{2} \mathrm{~h}^{-1}\right.$ cell $\left.^{-1}\right)$ may be $6 \mathrm{x}$ greater than respiration for the host-symbiont unit, indicating that zooxanthellae can provide all organic carbon requirements for their host (Jørgensen et al. 1985). The photosynthesis: respiration ratio in Orbulina universa (Fig. 1a) may vary between about 1-14, depending upon temperature and cell size (Rink et al. 1998; Lombard et al. 2009). The amount of carbon fixed by $O$. universa cells can exceed daily carbon requirements for the host-endosymbiont consortium, and it has been suggested that excess excreted carbon may help to attract their zooplankton prey (Lombard et al. 2009). Symbionts in O. universa appear to provide their hosts with $>50$ of their nitrogen requirements in nitrate replete conditions, the remainder of which is derived from feeding (Uhle et al. 1999). In nitrogen-deficient environments, symbionts provide O. universa with $>90 \%$ of its nitrogen requirements from the combined recycled pool $\left(\mathrm{NH}_{4}{ }^{+}\right)$(Uhle et al. 1999). These data suggest that feeding may be more important for phosphorus acquisition under nitratelimited conditions (Uhle et al. 1999). The role of $\mathrm{AcPh}$ and feeding in nutrient acquisition by foraminifera likely varies depending upon environmental conditions (e.g. nutrient levels) and their water column niche (e.g. pelagic vs. benthic).

\section{Cnidarian-algal symbioses}

The green hydra (Fig. 1b) is a freshwater cnidarian that undergoes a facultative mutual endosymbiotic association with Chlorella vulgaris within their endoderm (Table 1). Chlorohydra has been the subject of numerous laboratory studies due to their tractability as a model for intracellular recognition, their ability to 
asexually produce clonal buds, and the ease in which they are cultured (Trench 1979; Muscatine and McNeil 1989). Chlorohydra receives 10-60\% of photosynthetic products produced by Chlorella, mostly in the form of maltose (Muscatine and Lenhoff 1963; Cernichiari et al. 1969). Nearly half of all photosynthate gained by Chlorohydra may enter host glycogen storages (Mews and Smith 1982). Budding efficiencies (proportion of consumed food energy turned into new buds) of green Chlorohydra are 30-62\% greater than albino animals, indicating enhanced growth efficiency as a result of endosymbiont carbon production (Stiven 1965). While Chlorohydra can actively digest or exude Chlorella in order to maintain stasis in symbiont density, it is unclear how frequently such modes of regulation may not readily occur in nature (Muscatine and McNeil 1989). Recent observations of the green hydra, Chlorohydra viridissima, suggest that Chlorella are expelled as part of the apocrine mode of secretion, and via active exocytosis from endodermal digestive cells, during feeding on Artemia prey (Fishman et al. 2008). This phenomenon appears to benefit Chlorohydra by either allowing room for new endosymbiont growth, which occurs in conjunction with host mitosis hours after feeding, or perhaps to balance gains of mixotrophic energy resources (Fishman et al. 2008). Like other symbiotic cnidarians, Chlorohydra may also maintain endosymbiont density through regulation of nitrogenous waste (McAuley 1987; Rees 1989).

Symbiotic associations between the dinoflagellate Symbiodinium (= zooxanthellae) and a variety corals and anemones are widespread in temperate and especially tropical ecosystems (LaJeunesse et al. 2003; Thornhill et al. 2008). Perhaps the most globally significant of all endosymbiotic algal associations are the relationships between zooxanthellae and scleractinian (hard) corals in tropical reef ecosystems. Zooxanthellae reach astounding concentrations in coral tissues $\left(10^{6}\right.$ cells $\left.\mathrm{cm}^{-2}\right)$ compared to their potential free-living abundance in reef habitats, and collectively coral reefs represent a tremendous source of primary production for oligotrophic environments. In corals, zooxanthellae reside within vacuoles of gastroderm cells, where they provide energy for their hosts to carry out respiration and excretion, growth, and calcium carbonate $\left(\mathrm{CaCO}_{3}\right)$ deposition in their skeleton (Trench 1979; Muscatine 1990). Metabolite recycling is tightly coupled in cnidarian-Symbiodinium associations, resulting in extremely efficient (low loss rate from the symbiotic system) use of nitrogen (Trench 1979). One mechanism by which coral hosts are thought to regulate the growth of their zooxanthellae is through nitrogen limitation (Muscatine and Porter 1977; Falkowski et al. 1993). Under low environmental dissolved inorganic nitrogen (DIN) conditions, most of 
the nitrogen used by symbiotic zooxanthellae comes from recycled coral prey items (Muscatine et al. 1981; Grover et al. 2002). However, Symbiodinium are also capable of taking up environmental DIN, likely through seawater entering the coelenteric cavity of their host polyps, and can supply much of the nitrogen demands for both their host and themselves when concentrations are sufficient (Grover et al. 2002). Both corals and zooxanthellae are also capable of taking up dissolved free amino acids, which may contribute up to $25 \%$ of corals nitrogen needs (Grover et al. 2008). Feeding by corals inhibits uptake of ammonium by zooxanthellae (Grover et al. 2002), indicating that this internally recycled pathway is perhaps energetically more economical for Symbiodinium use.

Whether a result of host mediated nitrogen limitation (Muscatine and Porter 1977; Falkowski et al. 1993) or by uncharacterized photosynthate-release factors (Trench 1971), Symbiodinium relinquishes up to $90 \%$ of their photosynthate to their coral hosts (Table 1). Trench (Trench 1971) found that adding homogenate of coral host tissues induces the release of photosynthate from isolated zooxanthellae. The "host factor" that stimulates exudate release has been elusive in subsequent research, but potential candidates include protein amino acids (Sutton and Hoegh-Guldberg 1990; Gates et al. 1995), the nonprotein amino acid taurine (Wang and Douglas 1997), or an antagonist of calmodulin (Ritchie et al. 1997). The majority of photosynthate released back to coral hosts is in the form of glycerol and glycolic acid, however small quantities of essential amino acids and lipids are also provided (Muscatine and Cernichiari 1969; Wang and Douglas 1999). Released photosynthate is used primarily by corals for covering respiration costs and mucus production, while perhaps less than $1 \%$ is used for growth (Davies 1984) (Fig. 2a). While heterotrophic feeding by corals can provide about $30 \%$ their total carbon requirements, their dependencey upon heterotrophy varies greatly with depth, food availability, stress, and by species (Porter 1976; Muscatine et al. 1981; Grottoli et al. 2006). For example, after undergoing heat-induced bleaching (loss of zooxanthellae), some species of corals are able to cover over $100 \%$ of their daily carbon requirements by increased feeding, while others cannot (Grottoli et al. 2006).

Carbon dioxide respired by hard coral tissues is used as a substrate for photosynthesis by Symbiodinium, and also represents roughly $75 \%$ of the dissolved inorganic carbon used for calcification (Pearse 1970; Furla et al. 2000). Calcification in corals is fueled by translocation of photosynthetic products to actively growing skeletal regions (Pearse and Muscatin 1971). Coral tissues also maintain a $\mathrm{CO}_{2}$ 
concentrating mechanism that concentrates DIC from seawater into coral cells, through the coelenteric cavity, which is almost exclusively for zooxanthellae photosynthetic uptake (Furla et al. 2000).

\section{The physiology of organelle retention}

Organelle retention is a widespread ecological phenomenon in protists, but is relatively limited among the metazoa (Trench et al. 1969; Rumpho et al. 2000; Stoecker et al. 2009). Organelle retention is more common in marine habitats than in freshwater, and tends to be more prevalent in productive ecosystems (Stoecker et al. 2009). Frequently referred to as plastid sequestration or kleptoplasty, organelle retention involves the removal of plastids through modified grazing behavior. The process may also involve uptake of mitochondria, cytoplasm and endomembrane organelles, and even the prey nucleus (Johnson et al. 1995; Johnson et al. 2007; Koike and Takishita 2008). Hinde (Hinde 1983) described the long-term maintenance of plastids in the metazoan sea slug Elysia chlorotica as chloroplast farming. The comparison is apt, especially for E. chlorotica, which can maintain functional plastids for 10 months, while harvesting their photosynthate (Green et al. 2000). In contrast, many organelle-retaining protists keep their plastids for a mere 1-14 days (Stoecker and Silver 1990; Fields and Rhodes 1991; Skovgaard 1998), however the life spans of most protists (division and mortality rates) are within the same time span ( $<1-4$ days). While perhaps all cases of organelle retention are a form of mixotrophy, nuclear retention or karyoklepty, is functionally closer to phototrophy (Johnson and Stoecker 2005; Johnson et al. 2007). In karyoklepty, the prey nucleus must be reacquired perhaps once every cell generation through periodic ingestion of freeliving algal prey, and when present allows the host to fully utilize other sequestered prey organelles as if they were stably integrated (Johnson et al. 2007). Despite sharing many similarities to endosymbiosis, organelle retention is also similar to parasitoidism, in that the predator survives off its prey organelles and, in doing so, causes its death. Some notable organelle-retaining protists not discussed below includes Hatena arenicola (katablepharidophyta) (Okamoto and Inouye 2005), various benthic foraminifera (Lopez 1979; Bernhard and Bowser 1999), numerous species of dinoflagellates (Gast et al. 2007), and perhaps the metazoan crustacean Daphnia obtusa (Chang and Jenkins 2000).

Plastid-retaining ciliates 
Numerous species of ciliates are known to sequester plastids from free-living algal prey in both marine and freshwater ecosystems (Burkholder et al. 1967; Blackbourn et al. 1973; McManus and Fuhrman 1986; Jonsson 1987; Stoecker et al. 1987; Laval-Peuto and Rassoulzadegan 1988; Rogerson et al. 1989) (Table 2, Fig. 1c). After the phototrophic ciliate Myrionecta rubra, plastid-retaining oligotrich ciliates are likely the most ecologically widespread and abundant AcPhs in temperate pelagic marine ecosystems (Dale and Dahl 1987; Stoecker et al. 1987). While most plastidic oligotrichs have been shown to be mixotrophic, their benefit from phototrophy varies greatly with species (Stoecker et al. 1988; Stoecker et al. 1988-1989). Plastids in oligotrichs are surrounded by a host membrane, and are usually in the cell's periphery, away from digestive vacuoles (Laval-Peuto and Febvre 1986).The large oligotrich Loboea strobila is an obligate mixotroph, requiring algal plastids and light in order to maintain growth (Stoecker et al. 1988).

Photosynthetic rates per cell for this ciliate can be up to $12.6 \%$ of its cell carbon $\mathrm{h}^{-1}$, perhaps meeting $37 \%$ of its total carbon needs (Stoecker et al. 1988) (Table 2). Like most other AcPhs, much of the photosynthetic products are polysaccharides funneled towards host respiratory metabolism, with small amounts of fixed carbon entering lipid and protein anabolic pathways (Putt 1990) (Fig. 2b). Plastids in many oligotrich ciliates have a high turnover rate compared to other organelle-retaining protists, lasting only 9-40 h (Stoecker and Silver 1990), while those of L. strobila may persist for up to 14 days (Stoecker et al. 1988) (Table 2). The mixotrophic oligotrichs S. oculatum and S. stylifer have unusual trophic dynamics, stealing their plastids from the gametes of tide pool macroalgae (McManus et al. 2004) (Fig. 1c). The ciliate apparently sequesters not only the plastids from Enteromorpha sp. (Ulvophyeae) reproductive tissue and/or gametes, but also the eye spot, creating a dense eyespot region in their own cell (Fig. 1c; see reddish spot at cells base), likely used for phototaxis (McManus et al. 2004).

\section{Organelle-retaining dinoflagellates}

Dinoflagellates are a physiologically diverse group of protists, with about half of all species being heterotrophic, and nearly all phototrophic species being mixotrophs (i.e. phagotrophic phototrophs) (Schnepf and Elbrachter 1992; Jeong et al. 2005). Nearly all organelle retaining dinoflagellate species sequester their plastids from free-living cryptophyte algae (Larsen 1988; Fields and Rhodes 1991; Horiguchi and Pienaar 1992; Skovgaard 1998; Park et al. 2006; Koike and Takishita 2008; Garcia-Cuetos 
et al. 2009, 2010). One notable exception is an Antarctic dinoflagellate that sequesters organelles from the haptiphyte alga, Phaeocystis antarctica (Gast et al. 2007) (Fig. 1d). The mechanism by which most organelle-retaining dinoflagellates feed is by myzocytosis, which involves siphoning the inner contents of eukaryotic prey through a feeding peduncle or tube (Spero 1982). Frequently, not only the plastid is sequestered, but also most of the prey's cellular contents, which reside within a host vacuole (Larsen 1988). The prey's nucleus is usually selectively digested, or otherwise degrades quickly (Larsen 1988; Koike and Takishita 2008), while plastids and sometimes mitochondria remain for days. In a few cases the prey nucleus persists and may even be functional (i.e. karyoklepty) (Fields and Rhodes 1991; Gast et al. 2007), however limited data are available for such species. While many dinoflagellate species are known to sequester organelles from algal prey, surprisingly little physiological data is available concerning the benefits of these associations. Organelle-retention in dinoflagellates can be facultative or obligate mixotrophy, and photosynthesis enhances growth efficiency and likely provides certain essential nutrients (Skovgaard 1998).

The estuarine and coastal mixotrophic dinoflagellate Pfiesteria piscicida ingests a variety of prey and is even known to "micropredate" small fish by attaching to, and feeding on, their epidermis (Vogelbein et al. 2002). P. piscicida, has also been implicated as being kleptoplastic when it feeds upon cryptophyte algae (Lewitus et al. 1999). P. piscicida feeds with a peduncle, extracting cell contents from prey into food vacuoles and leaving behind the prey cell wall. Plastids have been shown to persist in vacuoles of starved P. piscicida under low light conditions $\left(10 \mu \mathrm{mol}\right.$ photons $\left.\mathrm{m}^{-2} \mathrm{~s}^{-1}\right)$ for at least a week, apparently fixing small amounts of carbon and accumulating starch grains (Lewitus et al. 1999). The dinoflagellate Gymnodinium 'gracilentum' also retains plastids from cryptomonad algae for up to a week in low light, and 2-3 days in moderate light (Skovgaard 1998). Under moderate light levels, G. 'gracilentum' gains about $51 \%$ of its carbon requirements from photosynthate, while under low light conditions greater than $90 \%$ stems from heterotrophic phagotrophy (Skovgaard 1998) (Table 2). Kleptoplastids in G. 'gracilentum' perform at much higher capacity than those of $P$. piscicida, however both dinoflagellates have a nearly two fold increase in growth when in saturating light levels for their phototrophic prey (Jakobsen et al. 2000; Feinstein et al. 2002). It is possible that light-enhanced growth in P. piscicida, may be due to a poorly 
understood phenomenon known in some heterotrophic protistan grazers, where growth rates increase in light (Strom 2001), rather than kleptoplastidy per se.

The genus Dinophysis has a number of species known to harbor plastids of cryptophycean origin (Hallegraeff and Lucas 1988), and at least one species, D. mitra, which possesses haptophyte algal plastids (Koike et al. 2005). Field populations of Dinophysis spp. are recognized as being mixotrophic (Jacobson and Andersen 1994), and have been widely suspected of kleptoplasty (Hackett et al. 2003; Janson 2004; Minnhagen and Janson 2006). Recently, cultures of D. acuminata, D. caudata, D. fortii, and D. infundibulus were established and shown to sequester their plastids from the phototropic ciliate Myrionecta rubra, which in turn requires free-living cryptophyte prey for its own survival (Park et al. 2006; Nagai et al. 2008; Nishitani et al. 2008; Park et al. 2008). Studies thus far have shown that Dinophysis spp. have a remarkable capacity to survive prolonged periods without M. rubra prey (Nagai et al. 2008; Nishitani et al. 2008), but reach maximum growth rates under high M. rubra and high light scenarios (Kim et al. 2008; Riisgaard and Hansen 2009). When D. infundibulus cultures are fed M. rubra prey and then starved, cells grow exponentially for about 2 weeks, after which time they slowly decline in number, with about $50 \%$ of the population dying after about 30 days (Nishitani et al. 2008). Thus Dinophysis spp. have the capacity to grow phototrophically for short periods, but must periodically feed on M. rubra in order to acquire plastids and gain carbon for heterotrophic digestion. D. acuminata, however, has been implicated as possessing “permanent" or stable plastids of cryptophycean orgin based on its unique plastid ultrastructural details (Garcia-Cuetos et al. 2010), despite the fact that it requires M. rubra prey to maintain growth, photosynthetic rates, and elevated chlorophyll concentrations (Setälä et al. 2005; Kim et al. 2008; Riisgaard and Hansen 2009). In well-fed cultured D. acuminata, 70-90\% of its gross carbon uptake is acquired by heterotrophic phagocytosis of M. rubra prey, while in low prey concentration the dinoflagellate appears to rely mostly upon photosynthesis for carbon uptake (Setälä et al. 2005; Riisgaard and Hansen 2009).

\section{Sacoglossan slugs}

Marine sacoglossan sea slugs of the genus Elysia are perhaps the most charismatic and bizarre organisms to practice $\mathrm{AcPh}$ (Fig. 1e), and are found in both coastal temperate to tropical ecosystems. Several members of the genus Elysia have been well studied for their unique evolutionary foray into the realm of 
phototrophy. Rather than hosting algal endosymbionts, as found in nudibranchs (Wägele and Johnsen 2001), sacoglossan slugs graze on green siphonaceous macroalgae and sequester plastids into tubule cells of their digestive diverticulum (Kawaguti and Yamasu 1965; Taylor 1967). Within the Elysia genus, there is a wide range in the slug's ability to maintain and utilize sequestered plastids (Greene 1970), indicating an evolutionary spectrum in their adaptive dependence upon phototrophy. In E. viridis, plastids sequestered from Codium fragile release 35-50\% of their photosynthate back to their host (Fig. 2b), most of which $(75 \%)$ is in the form of glucose (Trench et al. 1973; Hinde 1978). Using stable carbon isotope ratio data, Raven and others (Raven et al. 2001) determined that up to 0.6 of the total carbon input to certain sacoglossans is derived from photosynthesis. Recently, kleptoplasts in E. viridis were shown to mediate uptake of nitrite, ammonium, and urea (but not nitrate), which were found to be incorporated into glutamine and glutamate and could be inhibited by the addition of glutamine/glutamate synthetase inhibitors (Teugels et al. 2008).

Plastids in E. chorotica are extremely stable, remaining functional for as long as 8-10 months, the approximate life span of the slug in nature. In E. chlorotica collected from the wild and kept without food for nine months, photosynthetic rates decline markedly after five months and coincide with a drop in the slugs metabolic activity and respiration rates (Green et al. 2000) (Table 2). The plastids are derived from the chlorophyll c-containing macroalgae Vaucheria litorea (Xanthophyceae) and can provide the animal with its only source of energy and nutrition (Mujer et al. 1996; Green et al. 2000). While the longevity of sequestered plastids in E. chlorotica is remarkable, there is no evidence that the organelles are stably symbiotic. Kleptoplasts of the sea slug do not undergo division and the animal is not capable of de novo chlorophyll synthesis, thus they must reestablish the association each generation (Pierce et al. 1996). Intriguingly, for many months into starvation, plastids in E. chlorotica continue de novo synthesis of proteins, while maintaining electron transport activity and oxygen evolution (Green et al. 2000). Both plastid-encoded and algal prey nuclear-encoded plastid-targeted genes are expressed in E. chlorotica many months after sequestration, despite the absence of an algal nucleus (Mujer et al. 1996; Green et al. 2000; Rumpho et al. 2008). Recently, evidence of nuclear-encoded plastid-targeted algal genes, identical to their macroalgal algal, were independently found in the germ line of the slug, suggesting that gene transfers have occurred through predation (Pierce et al. 2007; Rumpho et al. 2008). These findings are the first evidence 
of a photosynthetic gene being transferred to a metazoan genome, the first case of functional and inheritable genes being transferred between two multicellular organisms, and the first documented case of gene transfer occurring in an organelle-retaining organism.

\section{Myrionecta rubra}

The marine ciliate M. rubra (= Mesodinium rubrum) is extremely widespread in coastal oceanic and estuarine ecosystems worldwide (Lindholm 1985). There are numerous accounts documenting the capacity of the ciliate to form non-toxic red tides in upwelling zones and estuaries (Taylor et al. 1971; Lindholm 1985). M. rubra has long been recognized as being phototrophic, with some of the highest productivity measurements (1000-2000 $\mathrm{mg} \mathrm{C} \mathrm{m}^{-3} \mathrm{~h}^{-1}$ ) ever recorded for phytoplankton during blooms (Ryther 1967; Packard et al. 1978), and with direct utilization of nitrate, ammonium and dissolved organic nitrogen (Packard et al. 1978; Wilkerson and Grunseich 1990). The ciliate possesses an endosymbiotic-like consortium of cryptophyte algal organelles, including numerous plastid-mitochondrial complexes and one or more cryptophyte nuclei (Taylor et al. 1971; Hibberd 1977; Oakley and Taylor 1978). While all strains of the ciliate that have been cultured require cryptophyte prey for sustained growth and maintenance of chlorophyll concentrations, disagreement exists as to the functional role of cryptophyte ingestion (Hansen and Fenchel 2006; Johnson et al. 2007). Studies of a temperate strain of the ciliate (Hansen and Fenchel 2006) concluded that the association is symbiotic and stable, while research on an Antarctic strain (Gustafson et al. 2000; Johnson et al. 2007) described the association as unstable and a case of organelle retention. Perhaps the most tantalizing resolution to these competing views is that this species complex is in the process of undergoing a tertiary plastid acquisition, with certain strains retaining the ancestral trait of active organelle sequestration, due to an inability to divide the cryptophyte nucleus. If this is indeed the case than complex forms of organelle retention appear to be one path to stable "endosymbiotic" associations, and perhaps a stable secondary or tertiary plastid acquisition.

The most detailed laboratory studies on the physiology of M. rubra are for the Antarctic strain of the ciliate, which practices karyoklepty, or nuclear retention (Johnson et al. 2007). In this strain cryptophyte plastids possess identical nucleomorph and plastid SSU rRNA genes and pigment profiles to the free-living cultured prey of the ciliate, and thus appear to be sequestered by the ciliate (Johnson et al. 2006). However, 
plastids in M. rubra undergo de novo division and pigment synthesis as long as the ciliate can continue to feed on cryptophyte prey (Gustafson et al. 2000; Johnson and Stoecker 2005; Johnson et al. 2007). The sequestered prey nucleus remains transcriptionally active within the ciliate for weeks, and has a half-life in the growing population of 10 days (Johnson et al. 2007). During this time the ciliate is capable of photoacclimation, using its plastids with equal efficiency to that of its prey (Johnson et al. 2006). The ciliate is capable of prolonged phototrophic growth after feeding on even small amounts of cryptophyte algae, gaining $>90 \%$ of is carbon needs from phototrophy, even when prey is abundant ( $Y$ ih et al. 2004; Johnson and Stoecker 2005; Park et al. 2007; Smith and Hansen 2007) (Table 2; Fig. 2c). Loss of prey nuclei from M. rubra cells results in a slow decline in growth, photosynthetic rates, and loss of chlorophyll (Johnson and Stoecker 2005; Johnson et al. 2007). Thus the ciliate appears to be essentially a functional phototrophy as long as it can periodically capture cryptophyte prey and reacquire a nucleus for regulating "symbiotic" organelles (Fig. 2c). While the ciliate is also capable of ingesting bacteria, a process that increases in low light, little is known regarding the nutritional benefit of bactivory in this species (Myung et al. 2006).

\section{Adaptations to AcPh}

AcPh has evolved through host-mediated interactions with algal prey through phagocytotic pathways. As in bacterial endosymbiotic associations, the similarities in the initiation, interaction and maintenance of phototrophic endosymbionts or sequestered organelles is conserved across a broad phylogenetic spectrum of hosts, including metazoans and protists. However, fundamental differences between multicellular and unicellular AcPhs, including their reproduction strategies, excretion rates, and non-cellular structures, complicate direct comparisons of energy budgets. In protists carbon contributions to growth are relatively straightforward because asexual somatic growth is directly proportional to population growth and sexual reproduction in many species is considered rare. In metazoans somatic growth of tissues can be difficult to quantify, costs of internal and/or external structures are greater, and gamete production occurs in parallel with somatic growth. The excretion of mucus by metazoan AcPhs can be a large sink of photosynthate (Crossland et al. 1980), while in protists excretion is considered a minor cost of photosynthetically fixed carbon (ter Kuile and Erez 1987; Putt 1990; Stoecker and Michaels 1991). 
All AcPhs are obligate phagotrophs, requiring ingestion of prey for satisfying carbon or other nutrient requirements. Numerous studies have illustrated that when food is unlimiting (an unlikely scenario for sustained periods in nature), many AcPhs are predominantly heterotrophic in their growth carbon requirements. In Paramecium bursaria, endosymbiont-mediated growth enhancement ceases when bacterial concentrations exceed $10^{7}$ bacteria $\mathrm{ml}^{-1}$ (Karakashian 1963). Under food-limiting conditions, growth rates of most AcPhs decline markedly. In corals, calcification and asexual growth (budding), as well as their zooxanthellae photosynthetic rates and pigment levels, are all greater when zooplankton prey are abundant (Houlbrèque et al. 2003). However, it is during food limitation or starvation, that the benefits of AcPh over strict heterotrophy are realized. In the cnidarian Chlorohydra, animals that possess endosymbiotic Chlorella can survive for about four weeks, while bleached Chlorohydra survive 10-12 days before dying (Muscatine and Lenhoff 1965). In Paramecium busaria, starved (no bacteria) cells without endosymbiotic Chlorella begin to precipitously die off after 3 days, while after 11 days symbiotic cells suffer no mortality and actually grow slightly (Karakashian 1963). Similar enhancement of survival may also occur in plastid retaining oligotrich ciliates, which cut respiratory costs by roughly $1-3 \%$ of their cellular carbon per hour when in light (Stoecker and Michaels 1991). Like metazoans, non-photosynthetic protists withstand starvation by lowering their respiration rates, subsisting on cellular stores, and through autophagous digestion of cytoplasm and organelles (Fenchel 1982). Many protists are known to form resting cysts, after which their metabolic rate is nearly undetectable (Caron et al. 1990). In the organelleretaining freshwater dinoflagellate Gymnodinium acidotum, cells excyst devoid of plastids, which they then sequester from free-living cryptophyte algae (Fields and Rhodes 1991).

The mixotrophic enhancement to growth efficiency is a unifying metabolic characteristic of AcPhs, and serves as a metabolic "bridge" over patchy food environments. However, the degree of host reliance upon acquired phototrophic carbon acquisition varies greatly across both endosymbiotic and organelle-retaining taxa $($ Table 1,2). Perhaps the least understood aspect of AcPh is why such relationships often tend to be obligate for the host (Tables 1,2). Many AcPhs have the potential to meet their carbon needs through heterotrophy alone, but if denied either light or suitable algal endosymbionts or prey they eventually stop growing. The oligotrich ciliate Laboea strobila fails to grow and decreases in cell volume when kept in the dark, even with abundant algal prey (Stoecker et al. 1988). When starved and given light, 
however, L. strobila had $84 \%$ greater survival and were twice as large as cells kept in dark (Stoecker et al. 1988). L. stobila illustrates that obligate AcPhs don't necessarily require that the majority of their carbon budget be derived from photosynthesis (Table 2). In cases where the nutrient requirements of AcPhs cannot be met through phagotrophy, photosynthesis is likely responsible for providing the host with essential growth factors or metabolic intermediates that they alone cannot synthesize. In such cases plastid or endosymbiont photosynthetic metabolism likely becomes integrated into host metabolic pathways, as seen in the production of essential fatty acids in the apicoplast of Toxoplasma gondii (Mazumdar et al. 2006) or the production of essential amino acids by zooxanthellae of some cnidarians (Wang and Douglas 1999).

One major difference, between endosymbiont and organelle-retaining AcPhs is that endosymbionts can undergo division, while sequestered plastids generally do not. Thus endosymbiont hosts tend to be more "closed systems", with greater amounts of nutrient recycling between symbionts and hosts. In contrast, while kleptoplasty is an efficient use of algal prey, it is wasteful compared to endosymbiosis in that it requires nearly constant replacement of aging plastids (Fig. 2b). Notable exceptions include the sea slug Elysia chlorotica and ciliate Myrionecta rubra, which both possess plastid associations that are essentially symbiotic, due to exceptional host adaptations (see above).

\section{From phagotrophy to phototrophy: the evolution of AcPh}

The remarkable evolutionary complexity of eukaryotes could be said to owe its roots to the evolution of phagocytosis and the dynamic eukaryotic endomembrane system (Cavalier-Smith 1981; Margulis 1981;

Reisser and Kurmeier 1984). The ability of eukaryotic cells to create internal compartments has yielded an astounding capacity for adaptation and metabolic flexibility. One such innovation was the capacity to harbor photosynthetic endosymbionts, which allowed the incorporation of phototrophic metabolism with existing heterotrophic pathways (Raven 1997; Raven et al. 2009). The intracellular environment of early eukaryotes was likely an active training ground for cells to adapt to symbiotic mutualism or enslavement, as it is today. Evidence of past phototrophy has been found in the genomes of non-photosynthetic lineages of protists (Reyes-Prieto et al. 2008), and in the vestigial non-photosynthetic plastids of several protist lineages (Köhler et al. 1997). Over a billion years ago, ancestors to the Plantae first acquired their plastids through a primary endosymbiotic event from a cyanobacterium (Yoon et al. 2004). Following the rise of 
the Plantae, yielding the green, red and glaucocystophyte algae, plastids radiated through the eukaryotic tree of life by secondary and tertiary endosymbiotic associations (Delwiche 1999; Archibald 2009). While the three major primary plastid-containing alga groups are likely derived from a single event (Yoon et al. 2004), the cyanelles of the euglyphid rhizarian Paulinella chromatophora are believed to be another primary plastid "in progress" (Theissen and Martin 2006; Yoon et al. 2006; Bhattacharya et al. 2007). The exact number of secondary plastid acquisitions from the Plantae to disparate eukaryotic lineages, is a subject of great controversy (Cavalier-Smith 1999; Burki et al. 2008; Sanchez-Puerta and Delwiche 2008). The event may have occurred five or six times, giving rise to the cryptophyte and haptophyte algae in one or perhaps two events, the heterokont algae, alveolates, euglenoids, and chlorarachniophytes in separate events (Sanchez-Puerta and Delwiche 2008). Despite efforts for a parsimonious solution, phylogenomic analysis of secondary algae suggests a past of plastid promiscuity in their evolution. In the diatoms, a group that has long since lost the capacity for phagotrophy, about half of their nuclear-encoded plastid-targeted genes are of green algal origin (Moustafa et al. 2009). Thus the plastid of red algal ancestory in all extant species of diatoms is likely the result of a plastid replacement event, early in their evolution (Moustafa et al. 2009). The metazoa is the only supergroup which practices AcPh and lacks any members with permanent plastids. The separation of reproductive and somatic cell lines in multicellular organisms, may preclude stable organelle acquisitions due to their nature as inheritable entities and not arising through ontogeny (Douglas 1994). However, as discussed above, this hasn't prevented the horizontal gene transfer of photosynthetic genes and adaptation to functional phototrophy in the sea slug Elysia chlorotica. In contrast, many unicellular organisms are ideal for stable plastid acquisitions, due to their dynamic endomembrane system, adaptable metabolism, and their ability to stably maintain associations with symbionts or foreign organelles as long as their division becomes synchronized with host mitosis. Such stable associations, however, must be precluded by massive endosymbiotic gene transfer and the evolution of a reliable targeting mechanism for nuclear-encoded, plastid-targeted genes (Bhattacharya et al. 2007).

The dinoflagellates best embody the promiscuity of plastid evolution, as they possess no fewer than three stably integrated plastid types in various species (Delwiche 1999), with evidence of several others in the making (Horiguchi and Pienaar 1994; Gast et al. 2007; Garcia-Cuetos et al. 2010). The major plastid type in dinoflagellates contains peridinin, an abundant carotenoid associated with chlorophyll-c 
containing light-harvesting complexes. Several genera are also known to have the carotenoid fucoxanthin associated with their chl-c containing plastids, originating from a tertiary endosymbiotic association with a haptophytes alga (Tengs et al. 2000). Perhaps the most unusual of dinoflagellate plastids are the chl-b containing plastids of prasinophyte origin found in dinoflagellates from the genus Lepidodinium (Watanabe et al. 1990). So why are dinoflagellates so prone to novel plastid acquisitions? About half of all dinoflagellate species are heterotrophic or parasitic, and most of the photosynthetic species are mixotrophic (Schnepf and Elbrachter 1992; Jeong et al. 2005). Many dinoflagellates that lack stable plastids, practice organelle retention and temporarily enslave algal plastids for photosynthesis (Skovgaard 1998; Jakobsen et al. 2000; Stoecker et al. 2009). In addition, several species are known to possess stable and reduced endosymbionts of diatom origin, lacking a cell wall, but sill possessing a nucleus and mitochondria (Horiguchi and Pienaar 1994). The story of plastid evolution in dinoflagellates is particularly vivid, and one that appears to be under constant revision. Evidence that all dinoflagellates may share a photosynthetic ancestor may be found in the presence of vestigial plastid genes in two basil non-photosynthetic dinoflagellate species (Sanchez-Puerta et al. 2006; Slamovits and Keeling 2008). However, phylogenetic evidence suggests that plastid loss or replacement has occurred in several dinoflagellates lineages (Saldarriaga et al. 2001). Such evolutionary "sea changes" in dinoflagellate plastids are likely due to their retention of ancestral heterotrophic tendencies (i.e. through mixotrophy), allowing them to adapt to changing biogeochemical (Quigg et al. 2003) and physiological (Raven 1997) selection through time.

While the actual series of events that have led to the acquisition of stable plastids or endosymbionts in acquired phototropic lineages are unknown, several extant species possess characteristics that appear to be secondary or tertiary endosymbiotic events that are "in progress" (Okamoto and Inouye 2005; Gast et al. 2007; Johnson et al. 2007; Rumpho et al. 2008). It is notable that all apparent "in progress" secondary or tertiary plastid acquisitions involve some form of organelle retention, rather than endosymbiosis. In those species that do appear to posses stable algal endosymbionts such as diatomcontaining dinoflagellates (Horiguchi and Pienaar 1994), the cell wall is absent and there are no clues for how the association arose. While organelle retention is frequently described as endosymbiosis, the processes share little resemblance in that one always involves mutualistic associations (when eukaryotic algae are involved) and the other predation. However, it is possible that the eventual evolutionary outcome 
of both processes may converge, resulting in a stable reduced endosymbiont-like state and eventually leading to a plastid.

\section{Conclusions}

The phenomenon of AcPh spans hosts from disparate eukaryotic supergroups and has led to independent plastid acquisitions in several of those lineages. Despite the enormous evolutionary distance amongst AcPhs, numerous similarities can be found in their physiological adaptations and ecological roles. Adaptation to $\mathrm{AcPh}$ requires an ability of the host to free endosymbionts or organelles from digestion and create differentiated vacuole membranes (Johnson et al. 1995; Kodama and Fujishima 2009), while some endosymbionts may adapt by resisting digestion (Kodama et al. 2007) or perhaps releasing recognition factors. AcPh leads to enhanced growth efficiency (Skovgaard 1998), provides access to oxygen (Finlay et al. 1996; Esteban et al. 2009) or nitrogenous compounds (Uhle et al. 1999; Grzymski et al. 2002) in limiting environments, provides essential nutrients (Wang and Douglas 1999), and in a few cases, acts as the major nutritional source (Muscatine et al. 1981; Mujer et al. 1996; Johnson and Stoecker 2005). While essential compounds are released to acquired phototroph hosts, few if any have been successfully characterized. Simple carbohydrates appear to be the dominant carbon contribution to host metabolism in most AcPhs, while lipids, amino acids, and other metabolites may also be released. Many hosts appear to have the ability to enhance photosynthetic release of endosymbionts or plastids, yet little is known regarding the mechanisms. Endosymbiosis is the most common form of AcPh where one or more nutrients, and therefore algal biomass, are limiting. Under such conditions, nutrients are efficiently recycled between symbionts and their hosts, allowing the endosymbiont to produce far more carbon than would normally be possibly in such an environment. In contrast, organelle retention generally involves nutrient flow in one direction and usually depends upon frequent replacement of sequestered plastids. Notable outliers among AcPhs include the organelle-retaining M. rubra and E. chlorotica, where the plastids are functioning in more of a stable "symbiotic" state.

\section{Acknowledgements}


I thank Elizabeth Gantt and Paul Falkowski for the invitation to submit this manuscript to this special issue on "Perspectives on the evolution of oxygenic photosynthesis". I thank Diane K. Stoecker, Fabrice Not, and Colomban de Vargas for illuminating discussions on AcPh, and Rebecca Gast, Dave Caron, Daniel Sher, George McManus, and Mary Rumpho for their generous image donations. Preparation of the manuscript was supported by NSF grant OCE-0851269.

\section{References}

Albers D, Wiessner W (1985) Nitrogen nutrition of endosymbiotic Chlorella spec. . Endocytobiosis and Cell Research 2:55-64

Anderson OR (1983) Radiolaria. Heidelberg, Germany: Springer-Verlag

Archibald JM (2009) The Puzzle of Plastid Evolution. Curr Biol 19:R81-R88

Berk SG, Parks LH, Ting RS (1991) Photoadaptation alters the ingestion rate of Paramecium bursaria, a mixotrophic ciliate. Appl Environ Microbiol 57:2312-2316

Bernhard JM, Bowser SS (1999) Benthic foraminifera of dysoxic sediments: chloroplast sequestration and functional morphology. Earth-Sci Rev 46:149-165

Berninger UG, Finlay BJ, Canter HM (1986) The spatial-distribution and ecology of zoochlorellae-bearing ciliates in a productive pond. J Protozool 33:557-563

Bhattacharya D, Archibald JM, Weber APM, Reyes-Prieto A (2007) How do endosymbionts become organelles? Understanding early events in plastid evolution. Bioessays 29:1239-1246

Blackbourn DJ, Taylor F, Blackborn J (1973) Foreign organelle retention by ciliates. J Protozool, vol 20 20:286-288

Burkholder PR, Burkholder LM, Almodóvar LR (1967) Carbon Assimilation of Marine Flagellate Blooms in Neritic Waters of Southern Puerto Rico. Bull Mar Sci 17:1-15

Burki F, Shalchian-Tabrizi K, Pawlowski J (2008) Phylogenomics reveals a new 'megagroup' including most photosynthetic eukaryotes. Biol Lett 4:366-369

Caron DA, Goldman JC, Fenchel T (1990) Protozoan respiration and metabolism. In: Capriulo GM, editor. Ecology of marine protozoa. New York: Oxford University Press. pp. 307-322

Caron DA, Michaels AF, Swanberg NR, Howse FA (1995) Primary productivity by symbiont-bearing planktonic sarcodines (Acantharia, Radiolaria, Foraminifera) in surface waters near Bermuda. J Plankton Res 17:103-129

Caron DA, Swanberg NR (1990) The Ecology of Planktonic Sarcodines. Rev Aquat Sci 3:147-180

Cavalier-Smith T (1981) The origin and early evolution of the eukaryotic cell. In: Carlile MJ, Collins JF, Moseley BEB, editors. Molecular and cellular aspects of microbial evolution. Cambridge: Cambridge University Press. pp. 33-84

Cavalier-Smith T (1999) Principles of protein and lipid targeting in secondary symbiogenesis: Euglenoid, dinoflagellate, and sporozoan plastid origins and the eukaryote family tree. J Euk Microbiol 46:347-366

Cernichiari E, Muscatine L, Smith DC (1969) Maltose Excretion by the Symbiotic Algae of Hydra viridis. Proc R Soc B, 173:557-576

Chang N, Jenkins DG (2000) Plastid endosymbionts in the freshwater crustacean Daphnia obtusa. J Crust Biol 20:231-238

Crossland CJ, Barnes DJ, Cox T, Devereux M (1980) Compartmentation and turnover of organic carbon in the staghorn coral Acropora formosa. Mar Biol 59:181-187

Dale T, Dahl E (1987) Mass occurrence of planktonic oligotrichous ciliates in a bay in southern Norway. J Plankton Res 9, no. 5:871-879

Davies PS (1984) The role of zooxanthellae in the nutritional energy-requirements of Pocillopora eydouxi Coral Reefs 2:181-186

Delwiche CF (1999) Tracing the thread of plastid diversity through the tapestry of life. Am Nat 154:S164S177 
Douglas AE (1994) Symbiotic interactions. New York: Oxford University Press Inc

Duguay LE (1983) Comparative laboratory and field studies on calcification and carbon fixation in foraminiferal-algal associations J Foraminifer Res 13:252-261

Esteban GF, Finlay BJ, Clarke KJ (2009) Sequestered organelles sustain aerobic microbial life in anoxic environments. Environ Microbiol 11:544-550

Faber WW, Lee JJ (1991) Feeding and growth of the foraminifer Peneroplis planatus (Fichtel and Moll) Monfort. Symbiosis 10:63-82

Falkowski PG, Dubinsky Z, Muscatine L, McCloskey L (1993) Population control in symbiotic corals Bioscience 43:606-611

Feinstein TN, Traslavina R, Sun MY, Lin SJ (2002) Effects of light on photosynthesis, grazing, and population dynamics of the heterotrophic dinoflagellate Pfiesteria piscicida (Dinophyceae). J Phycol 38:659-669

Fenchel T (1982) Ecology of heterotrophic microflagellates. III. Adaptations to heterogeneous environments. Mar Ecol Prog Ser 9:25-33

Fields SD, Rhodes RG (1991) Ingestion and retention of Chroomonas spp. (Cryptophyceae) by Gymnodinium acidotum (Dinophyceae). J Phycol 27:525-529

Finlay BJ, Clarke KJ, Cowling AJ, Hindle RM, Rogerson A, et al. (1988) On the abundance and distribution of protozoa and their food in a productive fresh water pond. Eur J Protistol 23:205217

Finlay BJ, Maberly SC, Esteban GF (1996) Spectacular abundance of ciliates in anoxic pond water: Contribution of symbiont photosynthesis to host respiratory oxygen requirements. FEMS Microbiol Ecol 20:229-235

Fishman Y, Zlotkin E, Sher D (2008) Expulsion of symbiotic algae during feeding by the green hydra - a mechanism for regulating symbiont density? PLoS ONE 3:e2603, 2601-2605

Flynn KJ, Mitra A (2009) Building the "perfect beast": modeling mixotrophic plankton. J Plankton Res 31:965-992

Fujita K, Fujimura H (2008) Organic and inorganic carbon production by algal symbiont-bearing foraminifera on northwest Pacific coral-reef flats. J Foraminifer Res 38:117-126

Furla P, Galgani I, Durand I, Allemand D (2000) Sources and mechanisms of inorganic carbon transport for coral calcification and photosynthesis. J Exp Biol 203:3445-3457

Garcia-Cuetos L, Moestrup O, Hansen PJ, Daugbjerg N (2009) The toxic dinoflagellate Dinophysis acuminata harbors permanent chloroplasts of cryptomonad origin, not kleptochloroplasts. Harmful Algae In Press, Corrected Proof

Garcia-Cuetos L, Moestrup O, Hansen PJ, Daugbjerg N (2010) The toxic dinoflagellate Dinophysis acuminata harbors permanent chloroplasts of cryptomonad origin, not kleptochloroplasts. Harmful Algae 9:25-38

Gast RJ, Caron DA (2001) Photosymbiotic associations in planktonic foraminifera and radiolaria. Hydrobiologia 461:1-7

Gast RJ, Moran DM, Dennett MR, Caron DA (2007) Kleptoplasty in an Antarctic dinoflagellate: caught in evolutionary transition? Environ Microbiol 9:39-45

Gates RD, Hoeghguldberg O, McFallngai MJ, Bil KY, Muscatine L (1995) Free amino acids exhibit anthozoan "host factor" activity: they induce the release of photosynthate from symbiotic dinoflagellates in vitro. PNAS 92:7430-7434

Green BJ, Li WY, Manhart JR, Fox TC, Summer EJ, et al. (2000) Mollusc-algal chloroplast endosymbiosis. Photosynthesis, thylakoid protein maintenance, and chloroplast gene expression continue for many months in the absence of the algal nucleus. Plant Physiol 124:331-342

Greene RW (1970) Symbiosis in sacoglossan opisthobranchs: functional capacity of symbiotic chloroplasts. Mar Biol 7:138-\&

Grottoli AG, Rodrigues LJ, Palardy JE (2006) Heterotrophic plasticity and resilience in bleached corals. Nature 440:1186-1189

Grover R, Maguer JF, Allemand D, Ferrier-Pages C (2008) Uptake of dissolved free amino acids by the scleractinian coral Stylophora pistillata. J Exp Biol 211:860-865

Grover R, Maguer JF, Reynaud-Vaganay S, Ferrier-Pages C (2002) Uptake of ammonium by the scleractinian coral Stylophora pistillata: Effect of feeding, light, and ammonium concentrations. Limnol Oceanogr 47:782-790 
Grzymski J, Schofield OM, Falkowski PG (2002) The function of plastids in the deep-sea benthic foraminifer, Nonionella stella. Limnol Oceanogr 47:1569-1580

Gustafson DE, Stoecker DK, Johnson MD, Van Heukelem WF, Sneider K (2000) Cryptophyte algae are robbed of their organelles by the marine ciliate Mesodinium rubrum. Nature 405:1049-1052

Hackett JD, Maranda L, Yoon HS, Bhattacharya D (2003) Phylogenetic evidence for the cryptophyte origin of the plastid of Dinophysis (Dinophysiales, Dinophyceae). J Phycol 39:440-448

Hallegraeff GM, Lucas IAN (1988) The marine dinoflagellate genus Dinophysis (Dinophyceae) photosynthetic, neritic and non-photosynthetic, oceanic species. Phycologia 27:25-42

Hansen PJ, Fenchel T (2006) The bloom-forming ciliate Mesodinium rubrum harbours a single permanent endosymbiont. Mar Biol Res 2:169-177

Hansen PJ, Miranda L, Azanza R (2004) Green Noctiluca scintillans: a dinoflagellate with its own greenhouse. Mar Ecol Prog Ser 275:79-87

Hemleben C, Spindler M, Anderson OR (1989) Modern Planktonic Foraminifera: Springer-Verlag

Hibberd DJ (1977) Ultrastructure of the cryptomonad endosymbiont of the red-water ciliate Mesodinium rubrum. J Mar Biol Assoc UK 57:45-61

Hinde R (1978) The metabolism of photosynthetically fixed carbon by isolated chloroplasts from Codium fragile (Chlorophyta: Siphonales) and by Elysia viridis (Mollusca: Sacoglossa). Biol J Linn Soc 10:329-342

Hinde R (1983) Retention of algal chloroplasts by molluscs. In: Goff LJ, editor. Algal Symbiosis A Continuum of Interaction Strategies. Cambridge: Cambridge University Press. pp. 97-107

Horiguchi T, Pienaar RN (1991) Ultrastructure of a Marine Dinoflagellate, Peridinium quinquecorne Abe (Peridiniales) from South-Africa with Particular Reference to Its Chrysophyte Endosymbiont. Bot Mar 34:123-131

Horiguchi T, Pienaar RN (1992) Amphidinium latum Lebour (Dinophyceae), a sand-dwelling dinoflagellate feeding on cryptomonads. Japan J Phycol. 40:353-363

Horiguchi T, Pienaar RN (1994) Ultrastructure of a new marine sand-dwelling dinoflagellate Gymnodinium quadrilobatum sp. nov. (Dinophyceae) with special reference to its endosymbiotic algae. Eur J Phycol 29:237-245

Houlbrèque F, Tambutte' E, Ferrier-Pagès C (2003) Effect of zooplankton availability on the rates of photosynthesis, and tissue and skeletal growth in the scleractinian coral Stylophora pistillata. J Exp Biol Ecol. 296:145-166

Jacobson DM, Andersen RA (1994) The discovery of mixotrophy in photosynthetic species of Dinophysis (Dinophyceae) - Light and electron-microscopic observations of food vacuoles in Dinophysis acuminata, D. norvegica and 2 heterotrophic dinophysoid dinoflagellates. Phycologia 33:97-110

Jakobsen HH, Hansen PJ, Larsen J (2000) Growth and grazing responses of two chloroplast-retaining dinoflagellates: effect of irradiance and prey species. Mar Ecol Prog Ser. 201:121-128

Janson S (2004) Molecular evidence that plastids in the toxin-producing dinoflagellate genus Dinophysis originate from the free-living cryptophyte Teleaulax amphioxeia. Environ Microbiol 6:1102-1106

Jeong HJ, Yoo YD, Park JY, Song JY, Kim ST, et al. (2005) Feeding by phototrophic red-tide dinoflagellates: five species newly revealed and six species previously known to be mixotrophic. Aquat Microb Ecol 40:133-150

Johnson MD, Oldach D, Delwiche CF, Stoecker DK (2007) Retention of transcriptionally active cryptophyte nuclei by the ciliate Myrionecta rubra. Nature 445:426-428

Johnson MD, Stoecker DK (2005) Role of feeding in growth and photophysiology of Myrionecta rubra. Aquat Microb Ecol 39:303-312

Johnson MD, Tengs T, Oldach D, Stoecker DK (2006) Sequestration, performance, and functional control of cryptophyte plastids in the ciliate Myrionecta rubra (Ciliophora). J Phycol 42:1235-1246

Johnson PW, Donaghay PL, Small EB, Sieburth JM (1995) Ultrastructure and ecology of Perispira ovum (Ciliophora, Litostomatea) - an aerobic, planktonic ciliate that sequesters the chloroplasts, mitochondria, and paramylon of Euglena proxima in a micro-oxic habitat. J Eukaryot Microbiol 42:323-335

Jones RI (1994) Mixotrophy in planktonic protists as a spectrum of nutritional strategies. Mar Microb Food Webs 8:87-96

Jonsson PR (1987) Photosynthetic assimilation of inorganic carbon in marine oligotrich ciliates (Ciliophora, Oligotrichina). Mar Microb Food Webs. 2:55-68 
Jørgensen BB, Erez J, Revsbech NP, Cohen Y (1985) Symbiotic photosynthesis in a planktonic foraminiferan, Globigerinoides sacculifer (Brady) studied with microelectrodes. Limnol Oceanogr 30:1253-1267

Kamako S, Hoshina R, Ueno S, Imamura N (2005) Establishment of axenic endosymbiotic strains of Japanese Paramecium bursaria and the utilization of carbohydrate and nitrogen compounds by the isolated algae. Eur J Protistol 41:193-202

Karakashian SJ (1963) Growth of Paramecium bursaria as influenced by the presence of algal symbionts. Physiol Zool 36:52-68

Kato Y, Imamura N (2008a) Effect of calcium ion on uptake of amino acids by symbiotic Chlorella F36ZK isolated from Japanese Paramecium bursaria. Plant Sci 174:88-96

Kato Y, Imamura N (2008b) Effect of sugars on amino acid transport by symbiotic Chlorella. Plant Physiol Biochem 46:911-917

Kato Y, Imamura N (2009) Amino acid transport systems of Japanese Paramecium symbiont F36-ZK. Symbiosis 47:99-107

Kawaguti S, Yamasu T (1965) Electron microscopy on the symbiosis between an elysioid gastropod and chloroplasts of a green alga. Biol J Okayama U 11:57-65

Kim S, Kang YG, Kim HS, Yih W, Coats DW, et al. (2008) Growth and grazing responses of the mixotrophic dinoflagellate Dinophysis acuminata as functions of light intensity and prey concentration. Aquat Microb Ecol 51:301-310

Kodama Y, Fujishima M (2007) Infectivity of Chlorella species for the ciliate Paramecium bursaria is not based on sugar residues of their cell wall components, but on their ability to localize beneath the host cell membrane after escaping from the host digestive vacuole in the early infection process. Protoplasma 231:55-63

Köhler S, Delwiche CF, Denny PW, Tilney LG, Webster P, et al. (1997) A plastid of probable green algal origin in apicomplexan parasites. Science 275:1485-1489

Koike K, Sekiguchi H, Kobiyama A, Takishita K, Kawachi M, et al. (2005) A novel type of kleptoplastidy in Dinophysis (Dinophyceae): Presence of haptophyte-type plastid in Dinophysis mitra. Protist $156: 225-237$

Koike K, Takishita K (2008) Anucleated cryptophyte vestiges in the gonyaulacalean dinoflagellates Amylax buxus and Amylax triacantha (Dinophyceae). Phycol Res 56:301-311

Kuile ter B, Erez J (1987) Uptake of inorganic carbon and internal cycling in symbiont-bearing foraminifera. Mar Biol 94:499-510

LaJeunesse TC, Loh WKW, van Woesik R, Hoegh-Guldberg O, Schmidt GW, et al. (2003) Low symbiont diversity in southern Great Barrier Reef corals, relative to those of the Caribbean. Limnol Oceanogr 48:2046-2054

Larsen J (1988) An ultrastructural-study of Amphidinium poecilochroum (Dinophyceae), a phagotrophic dinoflagellate feeding on small species of cryptophytes. Phycologia 27:366-377

Laval-Peuto M, Febvre MM (1986) On plastid symbiosis in Tontonia appendiculariformis. BioSyst 19:137-157

Laval-Peuto M, Rassoulzadegan F (1988) Autofluorescence of marine planktonic oligotrichina and other ciliates. Hydrobiologia 159:99-110

Lee JJ (2006) Algal symbiosis in larger foraminifera. Symbiosis 42:63-75

Lee JJ, Bock WD (1976) The Importance of Feeding in Two Species of Soritid Foraminifera with Algal Symbionts. Bull Mar Sci 26:530-537

Lee JJ, Zucker W (1969) Algal flagellate symbiosis in the foraminifer Archaias. J Protozool. 16:71-\&

Lewitus AJ, Glasgow HB, Burkholder JM (1999) Kleptoplastidy in the toxic dinoflagellate Pfiesteria piscicida (Dinophyceae). J Phycol 35:303-312

Lindholm T (1985) Mesodinium rubrum- a unique photosynthetic ciliate. Adv Aquat Microb 3:1-48

Lobban CS, Modeo L, Verni F, Rosati G (2005) Euplotes uncinatus (Ciliophora, Hypotrichia), a new species with zooxanthellae. Mar Biol 147:1055-1061

Lobban CS, Schefter M, Simpson AGB, Pochon X, Pawlowski J, et al. (2002) Maristentor dinoferus n. gen., n. sp., a giant heterotrich ciliate (Spirotrichea : Heterotrichida) with zooxanthellae, from coral reefs on Guam, Mariana Islands (vol 140, pg 411, 2002). Mar Biol 141:207-208

Lombard F, Erez J, Michel E, Labeyrie L (2009) Temperature effect on respiration and photosynthesis of the symbiont-bearing planktonic foraminifera Globigerinoides ruber, Orbulina universa, and Globigerinella siphonifera. Limnol Oceanogr 54:210-218 
Lopez E (1979) Algal chloroplasts in the protoplasm of three species of benthic foraminifera: taxonomic affinity, viability, and persistence. Mar Biol 53:201-211

Margulis L (1981) Symbiosis in cell evolution. San Francisco: W.H. Freeman \& Co. 419 p

Mazumdar J, Wilson EH, Masek K, Hunter CA, Striepen B (2006) Apicoplast fatty acid synthesis is essential for organelle biogenesis and parasite survival in Toxoplasma gondii. PNAS. 103:1319213197

McAuley PJ (1987) Nitrogen limitation and amino-acid metabolism of Chlorella symbiotic with green hydra. Planta 171:532-538

McManus GB, Fuhrman JA (1986) Photosynthetic pigments in the ciliate Laboea strobila from Long Island Sound, USA. J Plankton Res 8:317-327

McManus GB, Zhang H, Lin SJ (2004) Marine planktonic ciliates that prey on macroalgae and enslave their chloroplasts. Limnol Oceanogr 49:308-313

Mews LK, Smith DC (1982) The green Hydra symbiosis. VI. What is the role of maltose transfer from alga to animal? Proc R Soc B 216:397-413

Minnhagen S, Janson S (2006) Genetic analyses of Dinophysis spp. support kleptoplastidy. FEMS Microbiol Ecol 57:47-54

Moustafa A, Beszteri B, Maier UG, Bowler C, Valentin K, et al. (2009) Genomic footprints of a cryptic plastid endosymbiosis in diatoms. Science 324:1724-1726

Mujer CV, Andrews DL, Manhart JR, Pierce SK, Rumpho ME (1996) Chloroplast genes are expressed during intracellular symbiotic association of Vaucheria litorea plastids with the sea slug Elysia chlorotica. PNAS 93:12333-12338

Muscatine L (1990) The role of symbiotic algae in carbon and energy flux in reef corals In: Dubinsky Z, editor. Coral Reefs. Amsterdam: Elsevier. pp. 75-87

Muscatine L, Cernichiari E (1969) Assimilation of photosynthetic products of zooxanthellae by a reef coral. Biol Bull 137:506-523

Muscatine L, Lenhoff HM (1963) Symbiosis: On the Role of Algae Symbiotic with Hydra. Science 142:956-958

Muscatine L, Lenhoff HM (1965) Symbiosis of Hydra and Algae. II. Effects of limited food and starvation on growth of symbiotic and aposymbiotic Hydra. Biol Bull 129:316-328

Muscatine L, McCloskey LR, Marian RE (1981) Estimating the daily contribution of carbon from zooxanthellae to coral animal respiration. Limnol Oceanogr 26:601-611

Muscatine L, McNeil PL (1989) Endosymbiosis in Hydra and the evolution of internal defense systems. Am Zool 29:371-386

Muscatine L, Porter JW (1977) Reef corals: mutualistic symbioses adapted to nutrient-poor environments. Bioscience 27:454-460

Myung G, Yih W, Kim HS, Park JS, Cho BC (2006) Ingestion of bacterial cells by the marine photosynthetic ciliate Myrionecta rubra. Aquat Microb Ecol 44:175-180

Nagai S, Nitshitani G, Tomaru Y, Sakiyama S, Kamiyama T (2008) Predation by the toxic dinoflagellate Dinophysis fortii on the ciliate Myrionecta rubra and observation of sequestration of ciliate chloroplasts. J Phycol 44:909-922

Nishitani G, Nagai S, Takano Y, Sakiyama S, Baba K, et al. (2008) Growth characteristics and phylogenetic analysis of the marine dinoflagellate Dinophysis infundibulus (Dinophyceae). Aquat Microb Ecol 52:209-221

Oakley BR, Taylor FJR (1978) Evidence for a new type of endosymbiotic organization in a population of the ciliate Mesodinium rubrum from British Columbia. BioSyst 10:361-369

Okamoto N, Inouye I (2005) A secondary symbiosis in progress? Science 310:287-287

Packard T, Blasco D, Barber R (1978) Mesodinium rubrum in the Baja California upwelling system; Tomczak RaM, editor. Springer-Verlag, Berlin. 73-89 p

Park JS, Myung G, Kim HS, Cho BC, Yih W (2007) Growth responses of the marine photosynthetic ciliate Myrionecta rubra to different cryptomonad strains. Aquat Microb Ecol 48:83-90

Park MG, Kim S, Kim HS, Myung G, Kang YG, et al. (2006) First successful culture of the marine dinoflagellate Dinophysis acuminata. Aquat Microb Ecol 45:101-106

Park MG, Park JS, Kim M, Yih W (2008) Plastid dynamics during survival of Dinophysis caudata without its ciliate prey. J Phycol 44:1154-1163

Pearse VB (1970) Incorporation of metabolic $\mathrm{CO}_{2}$ into coral skeleton. Nature 228:383-\& 
Pearse VB, Muscatin L (1971) Role of symbiotic algae (zooxanthellae) in coral calcification. Biol Bull 141:350-363

Pierce SK, Biron RW, Rumpho ME (1996) Endosymbiotic chloroplasts in molluscan cells contain proteins synthesized after plastid capture. J Exp Biol 199:2323-2330

Pierce SK, Curtis NE, Hanten JJ, Boerner SL, Schwartz JA (2007) Transfer, integration and expression of functional nuclear genes between multicellular species. Symbiosis 43:57-64

Porter JW (1976) Autotrophy, heterotrophy, and resource partitioning in Caribbean reef-building corals. Am Nat 110:731-742

Putt M (1990) Metabolism of photosynthate in the chloroplast retaining ciliate Laboea strobila. Mar Ecol Prog Ser 60:271-282

Quigg A, Finkel ZV, Irwin AJ, Rosenthal Y, Ho TY, et al. (2003) The evolutionary inheritance of elemental stoichiometry in marine phytoplankton. Nature 425:291-294

Raven JA (1997) Phagotrophy in phototrophs. Limnol Oceanogr 42:198-205

Raven JA, Beardall J, Flynn K, Maberly SC (2009) Phagotrophy in the origins of photosynthesis in eukaryotes and as a complementary mode of nutrition in phototrophs: relation to Darwin's insectivorous plants. J Exp Bot 60:3975-3987

Raven JA, Walker DI, Jensen KR, Handley LL, Scrimgeour CM, et al. (2001) What fraction of the organic carbon in sacoglossans is obtained from photosynthesis by kleptoplastids? An investigation using the natural abundance of stable carbon isotopes. Mar Biol 138:537-545

Rees TAV (1989) The green hydra symbiosis and ammonium II. Ammonium assimilation and release by freshly isolated symbionts and cultured algae. Proc R Soc B 235:365-382

Reisser W (1976) The metabolic interactions between Paramecium bursaria Ehrbg. and Chlorella sp. in the Paramecium bursaria-symbiosis. II. Symbiosis-specific properties of the physiology and the cytology of the symbiotic unit and their regulation. Arch Microbiol 111:161-170

Reisser W (1986) Endosymbiotic associations of freshwater protozoa and algae. Prog Protist 1:195-214

Reisser W (1991) Ciliophora as microhabitats of different green algal species: model systems for an ecological concept of symbiosis formation. Mar Microb Food Webs 5:75-80

Reisser W (1992) Endosymbiotic associations of algae with freshwater protozoa and invertebrates. In: Reisser W, editor. Algae and Symbioses: Plants, Animals, Fungi, Viruses, Interactions Explored. Bristol: Biopress Limited. pp. 1-19

Reisser W, Benseler W (1981) Comparative studies on photosynthetic enzymes of the symbiotic Chlorella from Paramecium bursaria and other symbiotic and non-symbiotic Chlorella-strains. Arch Microbiol 129:178-180

Reisser W, Kurmeier B (1984) The endosymbiotic unit of Climacostomum virens and Chlorella sp. symbiotic features of the association and host-symbiont regulatory mechanisms. Protistologica 20:265-270

Reyes-Prieto A, Moustafa A, Bhattacharya D (2008) Multiple genes of apparent algal origin suggest ciliates may once have been photosynthetic. Curr Biol 18:956-962

Riisgaard K, Hansen PJ (2009) Role of food uptake for photosynthesis, growth and survival of the mixotrophic dinoflagellate Dinophysis acuminata. Mar Ecol Prog Ser 381:51-62

Rink S, Kuhl M, Bijma J, Spero HJ (1998) Microsensor studies of photosynthesis and respiration in the symbiotic foraminifer Orbulina universa. Mar Biol 131:583-595

Ritchie RJ, Grant AJ, Eltringham K, Hinde R (1997) Clotrimazole, a model compound for the host release factor of the coral Plesiastrea versipora. Aust J Plant Physiol 24:283-290

Rogerson A, Finlay BJ, Berninger UG (1989) Sequestered chloroplasts in the fresh-water ciliate Strombidium viride (Ciliophora, Oligotrichida). Transactions of the American Microscopical Society 108:117-126

Rumpho ME, Dastoor FP, Manhart JR, Lee J (2006) The Kleptoplast. In: Wise RR, Hoober JK, editors. The structure and function of plastids. New York: Springer. pp. 451-475

Rumpho ME, Summer EJ, Manhart JR (2000) Solar-powered sea slugs. Mollusc/algal chloroplast symbiosis. Plant Physiol 123:29-38

Rumpho ME, Worful JM, Lee J, Kannan K, Tyler MS, et al. (2008) Horizontal gene transfer of the algal nuclear gene psbO to the photosynthetic sea slug Elysia chlorotica. PNAS 105:17867-17871

Ryther JH (1967) Occurrence of red water off Peru. Nature 214:1318-\&

Saldarriaga JF, Taylor FJR, Keeling PJ, Cavalier-Smith T (2001) Dinoflagellate nuclear SSU rRNA phylogeny suggests multiple plastid losses and replacements. J Mol Evol 53:204-213 
Sanchez-Puerta MV, Delwiche CF (2008) A hypothesis for plastid evolution in chromalveolates. J Phycol 44:1097-1107

Sanchez-Puerta MV, Lippmeier JC, Apt KE, Delwiche CF (2006) Plastid genes in the nonphotosynthetic dinoflagellate Crypthecodinium cohnii. J Phycol 42:46

Schnepf E, Elbrachter M (1992) Nutritional strategies in dinoflagellates. A review with emphasis on cell biological aspects Eur J Protistol 28:3-24

Setälä O, Autio R, Kuosa H, Rintala J, Ylöstalo P (2005) Survival and photosynthetic activity of different Dinophysis acuminata populations in the northern Baltic Sea. Harmful Algae 4:337-350

Skovgaard A (1998) Role of chloroplast retention in a marine dinoflagellate. Aquat Microb Ecol 15:293301

Slamovits CH, Keeling PJ (2008) Plastid-derived genes in the nonphotosynthetic alveolate Oxyrrhis marina. Mol Biol Evol 25:1297-1306

Smith M, Hansen PJ (2007) Interaction between Mesodinium rubrum and its prey: importance of prey concentration, irradiance and $\mathrm{pH}$. Mar Ecol Prog Ser 338:61-70

Spero HJ (1982) Phagotrophy in Gymnodinium fungiforme (Pyrrhophyta): the peduncle as an organelle of ingestion. J Phycol 18:356-360

Spero HJ, Angel DL (1991) Planktonic sarcodines: microhabitat for oceanic dinoflagellates. J Phycol 27:187-195

Spero HJ, Parker SL (1985) Photosynthesis in the symbiotic planktonic foraminifer Orbulina universa and its potential contribution to oceanic primary productivity. J Foraminifer Res 15:273-281

Stiven AE (1965) The relationship between size, budding rate, and growth efficiency in three species of hydra. Res Popul Ecol 7:1-15

Stoecker DK, Johnson MD, de Vargas C, Not F (2009) Acquired phototrophy in aquatic protists. Aquat Microb Ecol 57:279-310

Stoecker DK, Michaels AE (1991) Respiration, photosynthesis and carbon metabolism in planktonic ciliates. Mar Biol 108:441-447

Stoecker DK, Michaels AE, Davis LH (1987) Large proportion of marine planktonic ciliates found to contain functional chloroplasts. Nature 326:790-792

Stoecker DK, Silver MW (1990) Replacement and aging of chloroplasts in Strombidium capitatum (Ciliophora, Oligotrichida). Mar Biol 107:491-502

Stoecker DK, Silver MW, Michaels AE, Davis LH (1988) Obligate mixotrophy in Laboea strobila, a ciliate which retains chloroplasts. Mar Biol 99:415-423

Stoecker DK, Sliver MW, Michaels AE, Davis LH (1988-1989) Enslavement of algal chloroplasts by four Strombidium spp. (Ciliophora, Oligotrichida). Mar Microb Food Webs 3:79-100

Strom SL (2001) Light-aided digestion, grazing and growth in herbivorous protists. Aquat Microb Ecol 23:253-261

Summerer M, Sonntag B, Sommaruga R (2007) An experimental test of the symbiosis specificity between the ciliate Paramecium bursaria and strains of the unicellular green alga Chlorella. Environ Microbiol 9:2117-2122

Sutton DC, Hoegh-Guldberg O (1990) Host-Zooxanthella Interactions in Four Temperate Marine Invertebrate Symbioses: Assessment of Effect of Host Extracts on Symbionts. The Biological Bulletin 178:175-186

Taylor DL (1967) The occurrence and significance of endosymbiotic chloroplasts in the digestive glands of herbivorous opisthobranchs. J Phycol 3:234-\&

Taylor FJR, Blackboun DJ, Blackboun J (1971) Red-water ciliate Mesodinium rubrum and its incomplete symbionts - review including new ultrastructural observations. J Fish Res Board Can 28:391-\&

Tengs T, Dahlberg OJ, Shalchian-Tabrizi K, Klaveness D, Rudi K, et al. (2000) Phylogenetic analyses indicate that the 19 ' hexanoyloxy-fucoxanthin-containing dinoflagellates have tertiary plastids of haptophyte origin. Mol Biol Evol 17:718-729

ter Kuile B, Erez J (1987) Uptake of inorganic carbon and internal cycling in symbiont-bearing foraminifera. Mar Biol 94:499-510

ter Kuile B, Erez J, Lee JJ (1987) The role of feeding in the metabolism of larger symbiont bearing foraminifera. Symbiosis 4:335-350

ter Kuile BH, Erez J (1991) Carbon budgets for two species of benthonic symbiont-bearing foraminifera Biological Bulletin 180:489-495 
Teugels B, Bouillon S, Veuger B, Middelburg JJ, Koedam N (2008) Kleptoplasts mediate nitrogen acquisition in the sea slug Elysia viridis. Aquatic Biology 4:15-21

Theissen U, Martin W (2006) The difference between organelles and endosymbionts. Curr Biol 16:R1016R1017

Thornhill DJ, Kemp DW, Bruns BU, Fitt WK, Schmidt GW (2008) Correspondence between cold tolerance and temperate biogeography in a western Atlantic Symbiodinium (Dinophyta) lineage. J Phycol 44:1126-1135

Tonooka Y, Watanabe T (2002) A natural strain of Paramecium bursaria lacking symbiotic algae. Eur J Protistol 38:55-58

Trench RK (1971) The physiology and biochemistry of zooxanthellae symbiotic with marine coelenterates. III. The effects of homogenates of host tissues on the excretion of photosynthetic products in vitro by Zooxanthellae from two marine Coelenterates. Proceedings of the Royal Society of London Series B-Biological Sciences 177:251-\&

Trench RK (1979) Cell biology of plant-animal symbiosis Annu Rev Plant Physiol Plant Mol Biol 30:485531

Trench RK, Boyle JE, Smith DC (1973) The association between chloroplasts of Codium fragile and the mollusc Elysia viridis II. Chloroplast ultrastructure and photosynthetic carbon fixation in $E$. viridis. Proceedings of the Royal Society of London Series B-Biological Sciences 184:63-\&

Trench RK, Greene RW, Bystrom BG (1969) Chloroplasts as functional organelles in animal tissues. J Cell Biol 42:404-\&

Uhle ME, Macko SA, Spero HJ, Lea DW, Ruddiman WF, et al. (1999) The fate of nitrogen in the Orbulina universa foraminifera-symbiont system determined by nitrogen isotope analyses of shell-bound organic matter. Limnol Oceanogr 44:1968-1977

Venn AA, Loram JE, Douglas AE (2008) Photosynthetic symbioses in animals. J Exp Bot 59:1069-1080

Vicente VP (1990) Response of sponges with autotrophic endosymbionts during the coral-bleaching episode in Puerto Rico. Coral Reefs 8:199-202

Vogelbein WK, Lovko VJ, Shields JD, Reece KS, Mason PL, et al. (2002) Pfiesteria shumwayae kills fish by micropredation not exotoxin secretion. Nature 418:967-970

Wägele M, Johnsen G (2001) Observations on the histology and photosynthetic performance of "solarpowered" opisthobranchs (Mollusca, Gastropoda, Opisthobranchia) containing symbiotic chloroplasts or zooxanthellae. Organisms Diversity \& Evolution 1:193-210

Wang JT, Douglas AE (1997) Nutrients, signals, and photosynthate release by symbiotic algae - The impact of taurine on the dinoflagellate alga Symbiodinium from the sea anemone Aiptasia pulchella. Plant Physiol 114:631-636

Wang JT, Douglas AE (1999) Essential amino acid synthesis and nitrogen recycling in an alga-invertebrate symbiosis. Mar Biol 135:219-222

Watanabe MW, Suda S, Inouya I, Chihara M (1990) Lepidodinium viride gen et sp. nov. (Gymnodiniales, Dinophyta), a green dinoflagellate with a chlorophyll A- and B-containing endosymbiont. J Phycol 26:741-751

Wilkerson FP, Grunseich G (1990) Formation of blooms by the symbiotic ciliate Mesodinium rubrum: the significance of nitrogen uptake. J Plankton Res 12:973-989

Williamson CE (1979) An ultrastructural investigation of algal symbiosis in white and green Spongilla lacustris (L.) (Porifera: Spongillidae). Trans Amer Microscop Soc 98:59-77

Yih W, Kim HS, Jeong HA, Myung G, Kim YG (2004) Ingestion of cryptophyte cells by the marine photosynthetic ciliate Mesodinium rubrum. Aquat Microb Ecol 36:165-170

Yoon HS, Hackett JD, Ciniglia C, Pinto G, Bhattacharya D (2004) A molecular timeline for the origin of photosynthetic eukaryotes. Mol Biol Evol 21:809-818

Yoon HS, Reyes-Prieto A, Melkonian M, Bhattacharya D (2006) Minimal plastid genome evolution in the Paulinella endosymbiont. Curr Biol 16:R670-R672 
Table 1. Select endosymbiotic acquired phototrophs, their endosymbionts, and relationship attributes. Abbreviations: U, uptake, F, feeding; S, stable

\begin{tabular}{lcccccc}
\hline \multicolumn{1}{c}{ Taxon } & Symbiont & Association & $\begin{array}{c}\text { \% host C } \\
\text { budget }\end{array}$ & Nitrogen & Max. fasting $^{1}$ & Sources \\
& & & & & \\
\hline Paramecium bursaria $^{a}$ & Chlorella & Facultative & $<50 ?$ & $\mathrm{U}, \mathrm{F}$ & $>11(3)$ & $\mathrm{S}$ \\
Chlorohydra viridissima $^{\mathrm{b}}$ & Chlorella & Facultative & $<50$ & $\mathrm{U}, \mathrm{F}$ & $28(12)$ & $\mathrm{S}$ \\
Foraminifera (various) $^{\mathrm{c}}$ & various & Facultative-obligate & $50-80$ & $\mathrm{U}, \mathrm{F}$ & - & $\mathrm{S}$ \\
Corals $^{\mathrm{d}}$ & Symbiodinium & Obligate & $60-90$ & $\mathrm{U}, \mathrm{F}$ & - & $\mathrm{S}$ \\
\hline
\end{tabular}

${ }^{1}$ Maximum fasting in days with $50 \%$ or less mortality of hosts with endosymbionts vs. without (in parentheses); ${ }^{\mathrm{a}}$ Reisser 1976 , ${ }^{\mathrm{b}}$ Muscatine and Lenhoff 1963 ,

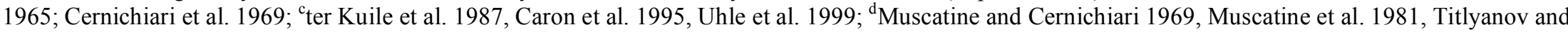
Titlyanova 2002 
Table 2. Select organelle retaining acquired phototrophs, their plastid sources, and relationship attributes. Abbreviations: U, uptake; F, feeding; S, stable ${ }^{2}$

\begin{tabular}{|c|c|c|c|c|c|c|}
\hline Taxon & Plastid type & Association & $\begin{array}{l}\text { \% host } \mathrm{C} \\
\text { budget }\end{array}$ & $\begin{array}{l}\text { Nitrogen } \\
\text { sources }\end{array}$ & Max. fasting $^{1}$ & Stability \\
\hline Laboea strobila $^{\mathrm{a}}$ & various & Obligate & 5- 37 & $\bar{F}$ & 6 & $2-14 \mathrm{~d}$ \\
\hline various oligotrich ciliates ${ }^{b}$ & various & Facultative-obligate & $5-15$ & $\mathrm{~F}$ & 2 & $<1-2 d$ \\
\hline Gyrodinium gracilentum ${ }^{\mathrm{c}}$ & cryptophyte & Facultative & $10-50$ & $\mathrm{~F}$ & $>7$ & $2-7 \mathrm{~d}$ \\
\hline Dinophysis spp. ${ }^{\mathrm{d}, e}$ & cryptophyte & Obligate & $10->50$ & $\mathrm{U}, \mathrm{F}$ & $30+$ & - \\
\hline Myrionecta rubra ${ }^{\mathrm{f}}$ & cryptophyte & Obligate & $?->95$ & $\mathrm{U}, \mathrm{F}$ ? & $50-100$ & $\sim \mathrm{S}$ \\
\hline Elysia chlorotica $^{\mathrm{g}}$ & Vaucheria litorea & Obligate & ?- >95 & $\mathrm{U}, \mathrm{F}$ & $300+$ & $\sim \mathrm{S}$ \\
\hline
\end{tabular}

${ }^{1}$ Maximum fasting in days with $50 \%$ or less mortality of hosts with plastids; ${ }^{2}$ Stability here refers to the longevity of the plastid or endosymbiont, where "stable"

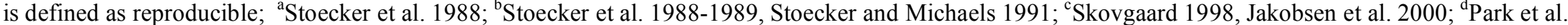
2007, Riisgaard and Hansen 2009; ${ }^{\mathrm{e}} \mathrm{Kim}$ et al. 2008; Johnson and Stoecker 2005, Johnson et al. 2007, Smith and Hansen 2007; ${ }^{\mathrm{g}}$ Green et al. 2000 , Teugels et al. 2008 
Figure Legends

Fig. 1. Images of the acquired phototrophs: the foraminifera Orbulina universa with endosymbiotic dinoflagellates (a), the cnidarian Chlorohydra with endosymbiotic Chlorella in its endoderm tissue (b), the oligotrich ciliate Strombidium sp. (perhaps S. oculatum) with green algal plastids (c), a kleptoplastidic dinoflagellate from the Ross Sea with Phaeocystis antarctica organelles (d) and the sea slug Elysia chlorotica with plastids from Vaucheria litorea (e). The scale bars in image (a) is $1 \mathrm{~mm}$ and in (d) $10 \mu \mathrm{m}$. Strombidium sp. in (c) is $50 \mu \mathrm{m}$ long, Chlorohydra in (b) is $5 \mathrm{~mm}$, and E. chlorotica in (d) is $2.5 \mathrm{~cm}$ in length.

Fig. 2. Conceptual diagrams of carbon flow in an idealized (a) endosymbiotic (e.g. Paramecium busaria), (b) organelle-retaining (e.g. Loboea strobila), and (c) karyokleptic (e.g. Myrionecta rubra) acquired phototrophs. Thick black arrows indicate flow of organic carbon. Thin dashed arrows indicate flow of inorganic carbon, oxygen $\left(\mathrm{O}_{2}\right)$, or cellular fluxes of prey, endosymbionts, or organelles. Circles with large dashed lines indicate an internal resource pool. Internal solid lines indicate host, symbiont, or organelle membrane and small dotted lines indicate a non-digestive host vacuole. All algal organelles and cytoplasm are shaded. Abbreviations: D, digestive vacuole; DIC, dissolved inorganic carbon; E, excretion; m, mitochondrion; $\mu$, growth; $\mathrm{N}$, nucleus; P, plastid; R, respiration; SM, sequestered mitochondrion; SN, sequestered nucleus; SP, sequestered plastid; question marks indicate unverified pathways. 
A.

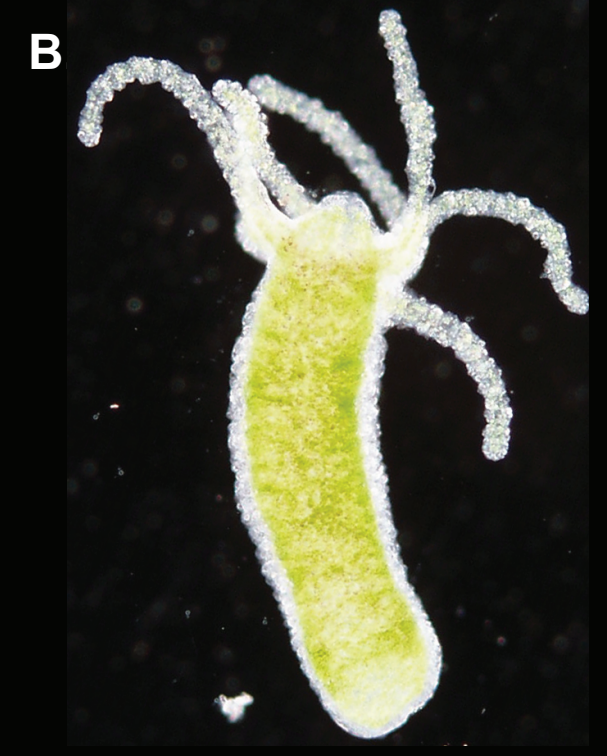

c.

D.

E.

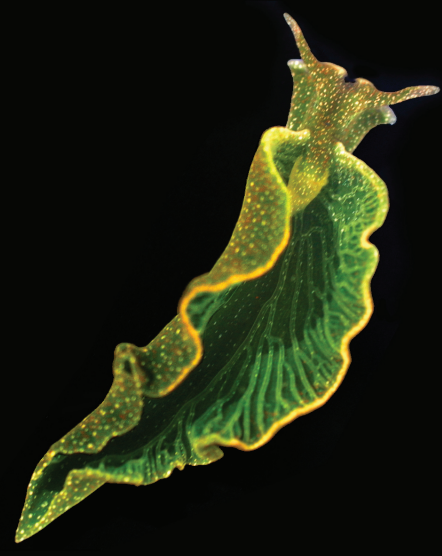



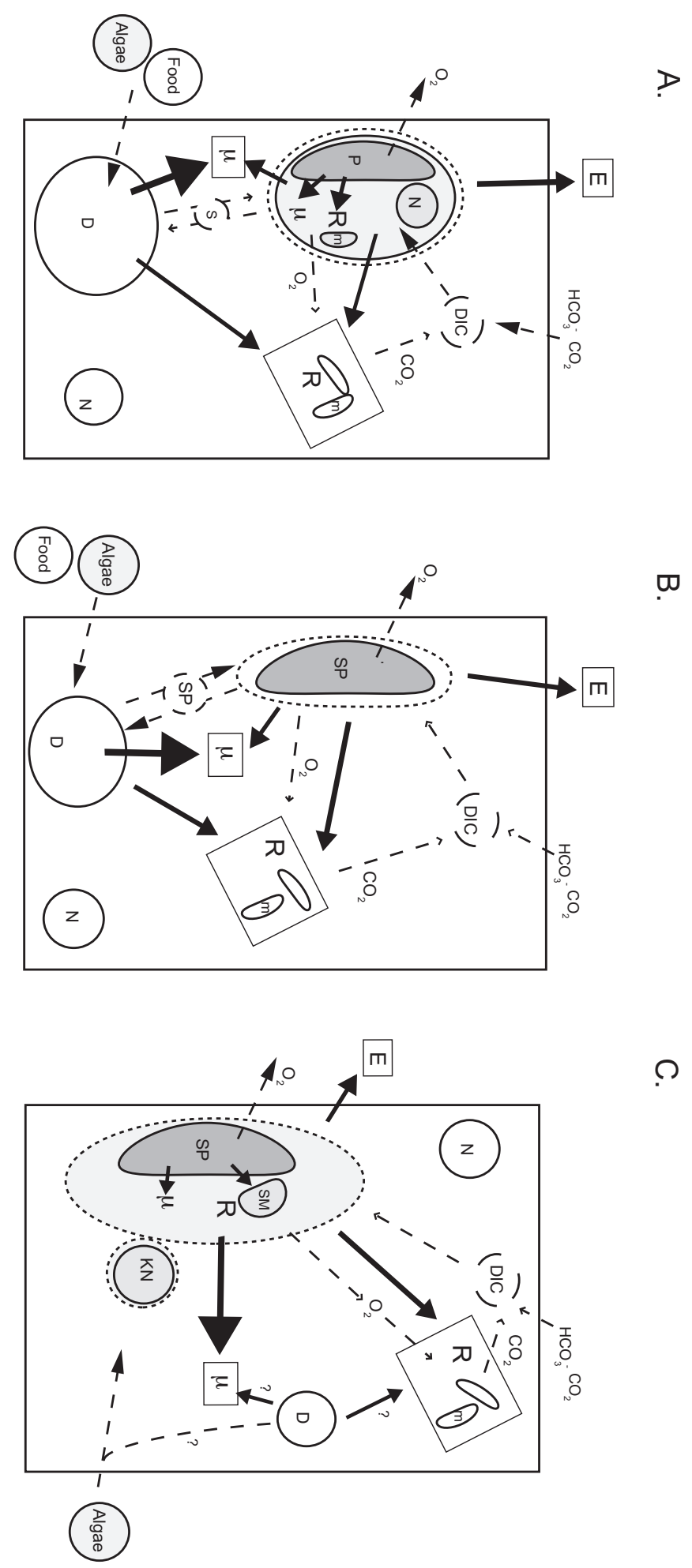